\title{
Study of the unknown vine genotype found in Abkhazia
}

\author{
Elena Ilnitskaya $^{1}{ }^{*}$, Marina Makarkina $^{1}$, Ilya Stepanov ${ }^{1}$, Madina Avidzba², and Victor \\ Malandzia ${ }^{3}$ \\ ${ }^{1}$ Federal State Budget Scientific Institution «North Caucasian Federal Scientific Center of \\ Horticulture, Viticulture, Wine-making», 350901 Krasnodar, Russia \\ ${ }^{2}$ State Scientific Institution «Institute of Agriculture of Sciences Academy Abkhazia», Sukhum, \\ Abkhazia \\ ${ }^{3}$ Abkhazian State University, Sukhum, Abkhazia
}

\begin{abstract}
The territory of Abkhazia belongs to the region of origin of the cultivated grapevine. Wild forms, intermediate forms between wild and cultivated grapevines and a variety of local native cultivars grow here. In the one of the private yards, a grapevine was found, the name and exact origin of which is not known. The vine showed no signs of fungal diseases in the humid conditions of the region during the absence of chemical treatment. The grape harvest was used to make red wine. DNAfingerprinting of the unknown genotype was performed to determine its origin. Analysis of the identified DNA profile for 9 SSR loci in the international VIVC database did not reveal coincides with any known cultivar. The methods of Principal coordinates analysis and Bayesian analysis were used to compare the unknown genotype with the genotypes of Vitis vinifera L of several geographic groups and varieties - interspecific hybrids. The closest genotype to the unknown form is the variety Isabella (V. labrusca $\mathrm{L} . \times V$. vinifera $\mathrm{L})$.
\end{abstract}

\section{Introduction}

The Western Transcaucasia and, especially, the subtropical zone of Georgia (its Western part) and the Central part of Abkhazia are recognized as centers of origin of the cultivated grapevine [1]. Here can be found wild forms, intermediate forms between wild and cultivated grapes and a variety of local ancient cultivars.

The region of Abkhazia has been known for its viticulture since ancient times. The local assortment was formed under the influence of various historical events. However, in the mid-twentieth century, significant areas of vineyards were destroyed when the region got phylloxera. At the same time, the American variety Isabella and some European cultivars on rootstocks were actively planted.

The glory of Abkhazian wines was mainly associated with variety Avasirkhva, Kachich, and Amlakhu - they were considered the best among the local cultivars. However, other

\footnotetext{
* Corresponding author: ilnitskaya79@mail.ru
} 
native varieties are of both interest for basic science and practical purposes. One of the main features' characteristic of the majority of Abkhazian native varieties are the late maturation period, non-shedding of berries and their resistance to rotting during a long stay on the vine. The study of the gene pool of grapevines in Abkhazia is important both for the purpose of expanding knowledge about native forms of grapes in various regions, and for searching for sources of valuable traits. Currently, the study of the gene pool is carried out using methods of molecular genetic analysis [2-12].

In the area of city Sukhum, a vine with a colored berry was found in one of the private courtyards, the precise origin of which is unknown (Fig. 1). Local residents described the grapes as "a long-growing variety for red wine here". It should be noted that the vine in the complete absence of chemical treatment, had no signs of fungal diseases, "foxy" (labrusca type) taste of berries was absent.

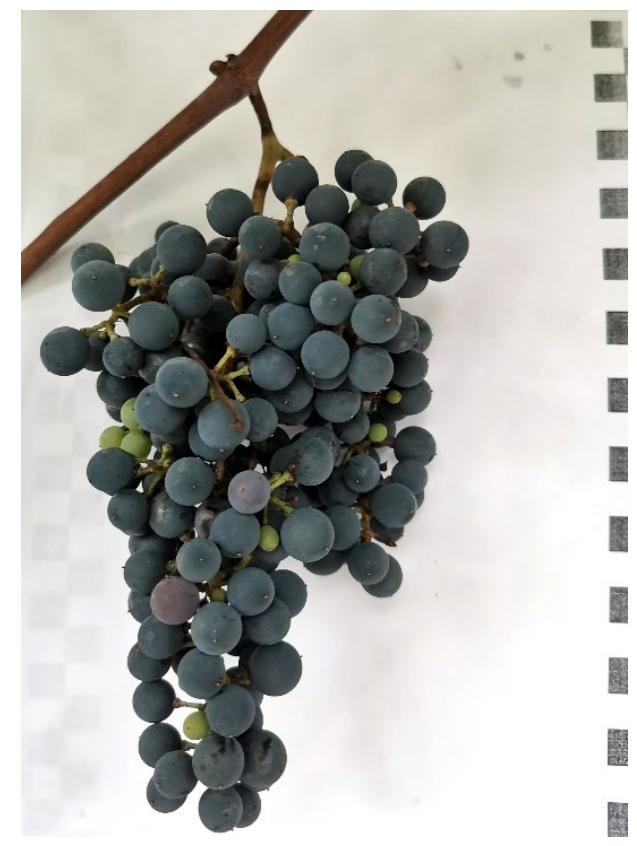

Fig. 1. Bunch of found unknown grapevine, Sukhum, September 2019.

The purpose of the study was to explore the possible origin of the found grapevine according to DNA analysis.

\section{Materials and Methods}

DNA was isolated from dried young leaf using a method based on the use of CTAB [13]. A standard set of 9 microsatellite markers (VVS2, VVMD5, VVMD7, VVMD25, VVMD27, VVMD28, VVMD32, VrZAG62, VrZAG79), recommended for DNA-fingerprinting of grapevines, was used for sample genotyping. [14]. Primer oligonucleotides with fluorescent tags were synthesized by «Syntol» (Russia). PCR was performed using reagents produced by « Sibenzim-M» (Russia). DNA amplification was performed using the BioRad device (USA). Amplified DNA fragments were separated by capillary electrophoresis on the ABI Prism 3130; the size of amplified fragments was determined using the GeneMapper 4.1 program. The DNA of the Cabernet Sauvignon variety was used as a reference genotype to clarify the size of amplified fragments. Genetic relationships were evaluated using the 
PCoA (Principal Coordinates Analysis) method in the Past 2.17c program. The Bayesian analysis was performed in the Structure 2.3.4 program.

\section{Results and Discussion}

Unknown grapevine has large or medium leaves, three-lobed. The teeth of leaf are short, depth of upper lateral sinuses is medium. Density of prostrate hairs between main veins on lower side of blade is none or very low. Petiole sinus is wide open. Length of petiole compared to length of middle vein is equal.

The genotype of the unknown vine form was profiled by 9 microsatellite loci (Table 1.). The identified DNA-profile was analyzed in the international database of grape variety DNA-profiles: VIVC [15]. When compared with data in the VIVC international database, no matches were found with any known varieties.

The analysis of alleles of each SSR locus showed that the identified allele is 268 nucleotide pairs in size at the locus VVMD5, it was found earlier only in Vitis riparia Michaux and in interspecific hybrids involving North American species, this allele has not been previously detected in any $V$. vinifera $\mathrm{L}$ variety.

Table 1. Results of DNA-marker analysis.

\begin{tabular}{|c|c|c|c|c|c|c|c|c|c|}
\hline \multirow[b]{2}{*}{ Sample } & \multicolumn{9}{|c|}{$\begin{array}{c}\text { Identified alleles of SSR-loci, } \\
\text { nucleotide pairs }\end{array}$} \\
\hline & $\tilde{n}^{\tilde{N}}$ & $\sum_{j}^{n}$ & $\sum_{j}^{\hat{S}}$ & 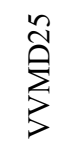 & $\stackrel{\hat{\tilde{N}}}{\xi}$ & $\underset{j}{\stackrel{\infty}{\sim}}$ & $\sum_{j}^{\stackrel{N}{j}}$ & 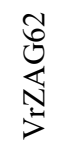 & \begin{tabular}{l}
$\stackrel{0}{0}$ \\
\multirow{J}{*}{} \\
$>$
\end{tabular} \\
\hline $\begin{array}{l}\text { Cabernet } \\
\text { Sauvignon }\end{array}$ & $\begin{array}{l}139 \\
151\end{array}$ & $\begin{array}{l}234 \\
242\end{array}$ & $\begin{array}{l}239 \\
239\end{array}$ & $\begin{array}{l}239 \\
249\end{array}$ & $\begin{array}{l}176 \\
190\end{array}$ & $\begin{array}{l}234 \\
236\end{array}$ & $\begin{array}{l}240 \\
240\end{array}$ & $\begin{array}{l}188 \\
194\end{array}$ & $\begin{array}{l}247 \\
247\end{array}$ \\
\hline Unknown & $\begin{array}{l}145 \\
151\end{array}$ & $\begin{array}{l}268 \\
268\end{array}$ & $\begin{array}{l}249 \\
251\end{array}$ & $\begin{array}{l}239 \\
249\end{array}$ & $\begin{array}{l}180 \\
212\end{array}$ & $\begin{array}{l}226 \\
244\end{array}$ & $\begin{array}{l}272 \\
272\end{array}$ & $\begin{array}{l}192 \\
204\end{array}$ & $\begin{array}{l}237 \\
259\end{array}$ \\
\hline
\end{tabular}

After conducting a DNA-analysis of the found sample, we suggested that the genotype may be a hybrid from the re-pollination of $V$. vinifera (local forms or European varieties) and varieties with the germplasm of North American species imported to the territory of Abkhazia at the beginning of the last century as rootstocks and phylloxera-resistant grape varieties.

To test the theory, a statistical analysis of molecular genetic analysis data was performed. The genetic relationships of unknown forms with the genotypes of European (Italian, French, Spanish), Georgian, Dagestan, Abkhazian and American varieties were evaluated using the PCoA (Principal Coordinates Analysis) method (Fig.2) and the genetic structure of the modeled sample was determined using the program Structure 2.3.4 (Bayesian analysis) (Fig.3). The DNA profiles of the compared genotypes of varieties were taken from the international database VIVC. The DNA profiles of the Abkhazian local varieties Amlakhu and Kachich at 9 microsatellite loci were obtained [16]. 


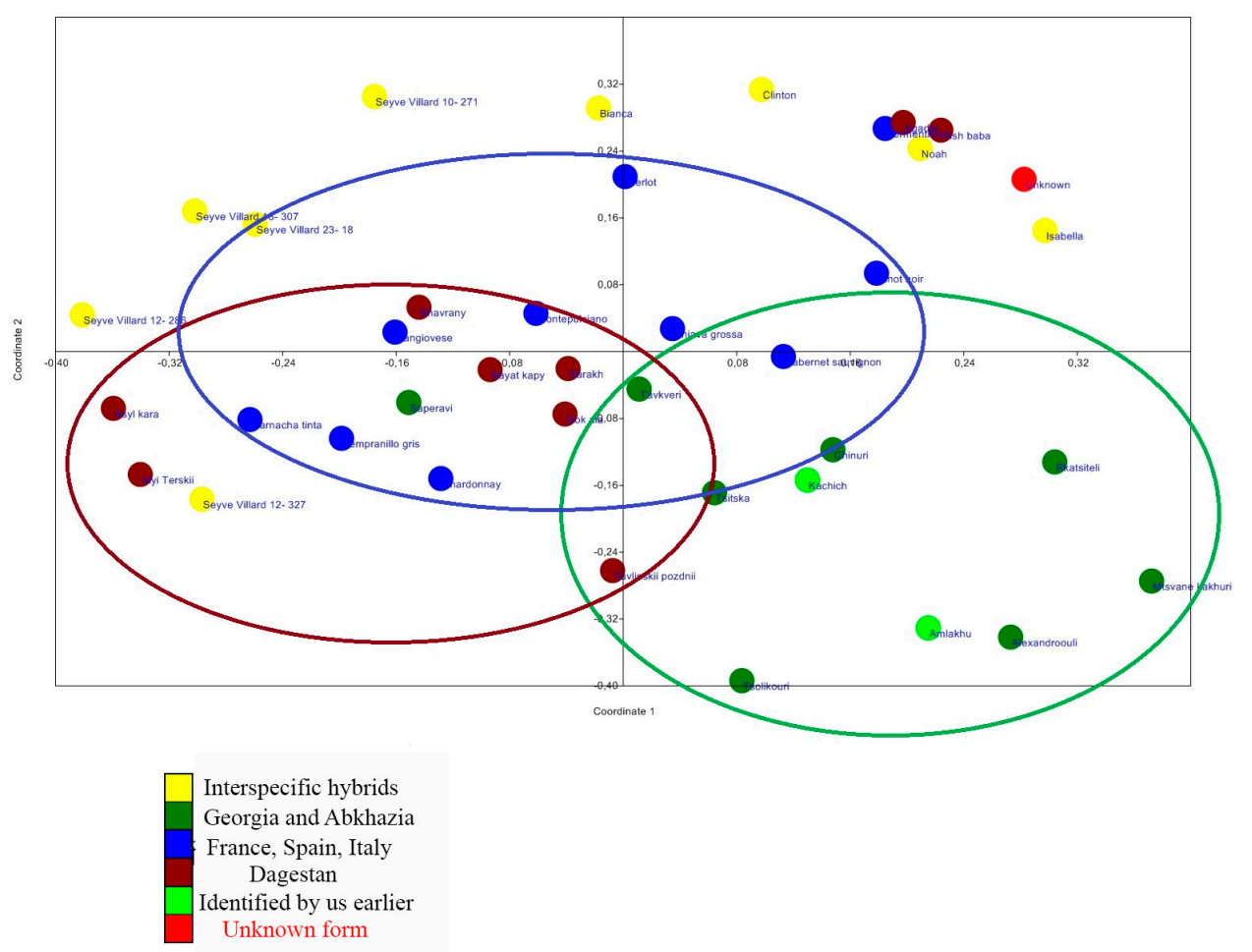

Fig. 2. Distribution of grape varieties in the main coordinate space according to SSR-profiling data

The distribution of genotypes in the space of the main coordinates allowed us to distinguish groups of European varieties, Georgian and Dagestan (Fig. 2). Moreover, Abkhazian varieties are located in the group of Georgian varieties, which confirms the proximity of these genotypes. It is shown that many Dagestani grapes are close to European varieties. The unknown form was in the out-group and the closest genotype to it was the Isabella variety. The Isabella variety is a hybrid $V$. labrusca $\mathrm{L} \times V$. vinifera $\mathrm{L}$. However, it is worth noting that in a separate group and close to an unknown form - Dagestan varieties $V$. vinifera Agadai, Rish baba and Italian - Vermentino, as well as the American variety-an interspecific hybrid of Noah, having in the pedigree $V$. riparia and $V$. labrusca. The obtained data confirm the assumption that the found form is most likely the result of natural hybridization $V$. vinifera and varieties with the American germplasm.

The assessment of the genetic structure of the modeled sample showed comparable results. Figure 3 shows that the genotype very similar to the found vine form (№18 in figure 3) is the variety Isabella (№2). From genotypes Vitis vinifera L among the analyzed sample the Abkhazian native variety Kachich is more similar to the unknown form (№16) and the Dagestan variety Rish baba (№33). 


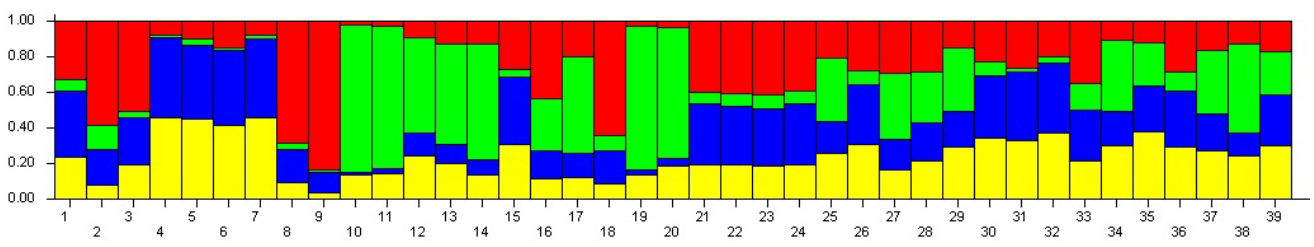

1 - Bianca, 2 - Isabella, 3 - Seyve Villard 10- 271, 4 - Seyve Villard 12- 286, 5 - Seyve Villard 12- 327, 6 - Seyve Villard 18- 307, 7 - Seyve Villard 23- 18, 8 - Clinton, 9 - Noah; (гибриды)

10 - Mtsvane kakhuri, 11 - Rkatsiteli, 12 - Tavkveri, 13 - Tsitska, 14 - Tsolikouri, 15 - Saperavi, 16 - Kachich, 17 - Amlakhu, 18 - Unknown, 19 - Alexandroouli, 20 - Chinuri; (V. vinifera Грузии и Абхазии)

21 - Cabernet sauvignon, 22 - Chardonnay, 23 - Merlot, 24 - Pinot noir; 25 - Montepulciano; 26 Sangiovese; 27 - Chiava grossa; 28 - Vermentino; 29 - Tempranillo gris; 30 - Garnacha tinta;

31 - Alyi Terskii; 32 - Asyl kara; 33 - Rish baba; 34 - Sarakh; 35 - Shavrany; 36 - Bayat kapy; 37 - Agadai; 38 - Gok ala; 39 - Tavlinskii pozdnii

Fig. 3. Bar plot Bayesian analysis grape variety

The results do not contradict the assumption that the found genotype is a hybrid of a North American species and $V$. vinifera. Direct comparison of the DNA-profiles of the Isabella variety and the found genotype gave the following results:

Unknown form: VVS2 ${ }_{145} \underline{151}$ VVMD5 268268 VVMD7 $_{249} 251$ VVMD25 239249 VVMD27 1180212 VVMD28 226244 VVMD32 $272 \underline{272}$ VrZAG62 194204 VrZAG79 237259

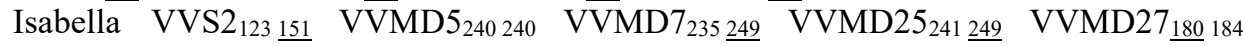
VVMD28 226236 VVMD32 248 272 VrZAG62 $202 \underline{204}$ VrZAG79 237247

Alleles of the same size are present in 8 of the 9 analyzed SSR-loci of genotypes (underlined). Only in the locus VVMD5 the genotypes that being compared do not share a common allele. Perhaps the found genotype is a offspring of the Isabella variety, the absence of an allele at the locus VVMD5 could be a result of mutation.

If we assume that the resistance of the found grapevine sample is determined, among other things, by genes of $V$. labrusca, the absence of the "foxy" grape flavor, the distinctive taste of $V$. labrusca - valuable feature. The found genotype may be interesting for breeding as a source of resistance. In the autumn of 2019, a biochemical analysis of the grapes was performed. The berry juice contains a high supply of phenolic substances $\left(3156 \mathrm{mg} / \mathrm{dm}^{3}\right)$ and a high accumulation of anthocyanins $\left(2100 \mathrm{mg} / \mathrm{dm}^{3}\right)$ with moderate sugar accumulation $\left(21 \mathrm{~g} / 100 \mathrm{~cm}^{3}\right)$ and high titrated acidity $\left(10 \mathrm{~g} / 100 \mathrm{~cm}^{3}\right)$. These indicators characterize the form as a promising genotype for creating red wines.

\section{Conclusion}

According to the DNA analysis and statistical data processing, it can be concluded that the found unknown grapevine is not an indigenous genotype of Abkhazia. Most likely, the studied sample is the result of natural hybridization and Isabella ( . labrusca L. $\times V$. vinifera $\mathrm{L}$ ), which was actively planted in the region in the last century, and $V$. vinifera $\mathrm{L}$. varieties. However, this grapevine sample is missing "foxy" the distinctive taste of $V$. labrusca when this form is characterized by good tolerance to pathogens. The found vine can be used in the breeding of resistant wine grape varieties.

The reported study was funded by RFBR and ASA according to the research project № 19-516-40001 


\section{References}

1. J. Ekhvaia, M. Gurushidze, F. R. Blattner, M. Akhalkatsi, Genetic resources and crop evolution, 61(8), 1507-1521 (2014) https://link.springer.com/article/10.1007/s10722014-0125-2

2. F. Grassi, R. Arroyo-Garcia, Frontiers in Plant Science, 11, 1176 (2020) https://www.frontiersin.org/articles/10.3389/fpls.2020.01176/full

3. A. Khadivi, A. Gismondi, A Canini, Agroforestry systems, 93, 435-447 (2019) https://doi.org/10.1007/s10457-017-0134-1

4. M. Cantos, R. Arroyo-García, J. L. García, M. Lara, R. Morales, M. A. Lopes, A. Gallardo, C. A. Ocete, A. Rodriguez, J. M. Valle, R. Vaca, M. González-Maestroa, H. Bánátih, R. Ocetee., Comptes rendus biologies, 340(3), 164-177 (2017) https://doi.org/10.1016/j.crvi.2017.01.004

5. B. Işçi, Biotechnology \& Biotechnological Equipment, 33(1), 1303-1310 (2019) https://doi.org/10.1080/13102818.2019.1664320

6. Z. Knezović, A. Mandić, N. Perić, J. Beljo, M. Z. Mihaljević, Croatian Review of Economic, Business and Social Statistics, 2(3), 1-9 (2017) https://doi.org/10.1515/crebss-2017-0005

7. G. Marsal, J. J. Méndez, J. M. Mateo, S. Ferrer, F. Zamora, F. Fort, J.M. Canals, OENO One, 4(53), 667-680 (2019) https://doi.org/10.20870/oeno-one.2019.53.4.2404

8. M. Rahali, D. Migliaro, Z. Laiadi, N. Bertazzon, E. Angelini, M. Crespan, Vitis, 4(58), 153-158 (2019) https://doi.org/10.5073/vitis.2019.58.153-158

9. M. Papapetrou, D. Loukovitis, O. Papadopoulos, Z. Kazlari, A. Peristeraki, S. Arsenova, S. Koundouras, Diversity, 12(7), $273 \quad$ (2020) https://doi.org/10.3390/d12070273

10. A. C. Bibi, E. D. Gonias, A. G. Doulis, Biochemical genetics, 58(2), 294-321 (2020) https://doi.org/10.1007/s10528-019-09943-Z

11. F. Taheri, H. Darzi Ramandi, International Journal of Fruit Science, 1-18 (2020) https://doi.org/10.1080/15538362.2020.1736235

12. M. Dallakyan, S. Esoyan, B. Gasparyan B., A. Smith, N. Hovhannisyan, Genetic $\begin{array}{llll}\text { Resources and Crop Evolution, 67(1), 999-1024 (2020) } & \end{array}$ https://link.springer.com/article/10.1007\%2Fs10722-020-00897-5

13. S. Lo Piccolo, A. Alfonzo, G. Conigliaro, G. Moschetti, S. Burruano, A. Barone, African Journal of Biotechnology, 11(45), 10305-10309 (2012) DOI:10.5897/AJB11.3023 https://academicjournals.org/journal/AJB/articleabstract/956CF8231201

14. Vitis international variety catalogue (VIVC), SSR-Marker data (2020) https://www.vivc.de/index.php?r=aboutvivc\%2Fssrmarker

15. Vitis international variety catalogue (VIVC), Microsatellites by profile (2020) https://www.vivc.de/index.php? $\mathrm{r}=$ eva-analysis-mikrosatelliten-vivc $\% 2$ Findex

16. E. T. Ilnitskaya, M. V. Makarkina, S. V. Tokmakov, A. A. Krasilnikov, V. Ch. Aiba, M. A. Avidzba, Fruit growing and viticulture of South Russia, 61(1), 33-43 (2020) http://journalkubansad.ru/pdf/20/01/03.pdf 